\title{
TINGKAT DEPRESI DITINJAU DARI LATAR BELAKANG PENYEBAB KECACATAN PADA PENYANDANG TUNA DAKSA
}

\author{
Endah Fajri Arianti ${ }^{1}$, Partini $^{2}$ \\ ${ }^{1,2}$ Fakultas Psikologi Universitas Muammadiyah Surakarta \\ 1efarianti.ea@gmail.com
}

\begin{abstract}
The purpose of this study to determine the difference of depression in terms of background of the causes of disability in the disabled in BBRSBD Surakarta. The hypothesis of this study is that there is a difference in depression rate between disabled people due to accidents is higher than the level of depression of people with birth defects. This research uses quantitative approach of comparation. The population of this study is the disabled in the BBRSBD amounted to 128 tuna daksa. Sampling technique using purposive sampling. The sample in this research is 80 tuna daksa. 40 persons with 40 persons with 40 persons with 40 persons with 40 persons with 40 persons with visual impairment. Hypothesis test in this research using independent sample t-test. These results indicate that there is a difference in depression rate between persons with impairment due to accidents is higher than those with birth defects.
\end{abstract}

Keywords:; depression, physical disability, congenital

Abstraksi Tujuan penelitian ini untuk mengetahui perbedaan depresi ditinjau dari latar belakang penyebab kecacatan pada penyandang tuna daksa di BBRSBD Surakarta. Hipotesis penelitian ini adalah ada perbedaan tingkat depresi antara penyandang tuna daksa akibat kecelakaan lebih tinggi dibanding tingkat depresi penyandang tuna daksa bawaan lahir. Penelitian ini menggunakan pendekatan kuantitatif komparasi. Populasi penelitian ini adalah tuna daksa di BBRSBD berjumlah 128 tuna daksa. Teknik pengambilan sampel menggunakan purposive sampling. Sampel dalam penelitian ini bejumlah 80 tuna daksa. Penyandang tuna daksa bawaan lahir berjumlah 40 orang dan penyandang tuna daksa akibat kecelakaan berjumlah 40 orang. Uji hipotesis dalam penelitian ini menggunakan independent sample t-test. Hasil ini menunjukan terdapat perbedaan tingkat depresi antara penyandang tuna daksa akibat kecelakaan lebih tinggi dibanding penyandang tuna daksa bawaan lahir.

Kata kunci: depresi, tuna daksa, bawaan lahir

\section{PENDAHULUAN}

Angka kecelakaan menurut data Global Status in Road Safety yang dikeluarkan WHO pada tahun 2015 sebanyak 1,24 juta orang di seluruh dunia meninggal. Rata-rata setiap harinya orang meninggal akibat kecelakaan lalu lintas sekitar 3400 orang (Mardianto, 2016). Angka kecelakaan kerja yang terjadi di Indonesia pada tahun 2015 data Badan Penyelenggara Jaminan Sosial (BPJS) ketenagakerjaan dari awal tahun hingga akhir hingga akhir tahun 2015 telah terjadi kecelakaan kerja sebanyak 105.182 kasus, diantaranya 2.375 kasus mengakibatkan kematian (Cicilia, 2016).

Berdasarkan data dari Badan Pusat Statistik (BPS) Republik Indonesia tahun 2010, tercatat jumlah penyandang disabilitas $4,74 \%$ yaitu mencapai 9.046.000 jiwa dari 237 juta jiwa (Fachrudin, 2015). Populasi penyandang 
disabilitas menurut Survei Sosial Ekonomi Nasional (Susenas) tahun 2012 adalah sebesar 2,45\% (6.515.500 jiwa) dari 244.919.000 estimasi jumlah penduduk Indonesia tahun 2012 (Diono, Mujaddid dan Prasetya, 2014). Pada 2016 BPS menerbitkan survei ketenagakerjaan nasional (sakernas).jumlah penyandang disabilitas di Indonesia sebesar 12,15\%. Penyandang disabilitas di Indonesia termasuk kategori sedang sebanyak 10,29 persen dan kategori berat sebanyak 1,87 persen (Susilawati \& Aminah, 2016).

Balai Besar Rehabilitasi Sosial Bina Daksa (BBRSBD) merupakan lembaga pendidikan dan pelatihan bagi penyandang tuna daksa.Balai pendidikan dan pelatihan untuk melatih para individu yang memiliki kekurangan fisik untuk dapat memiliki ketrampilan dan mampu bekerja atau mendirikan usaha sendiri sehingga terwujudnya kemandirian dan kesejahteraan individu penyandang tuna daksa, untuk mempersiapkan dan membekali individu tuna daksa dengan kecacatan tubuh agar dapat menjadi mandiri dan sejahtera.

Jumlah siswa di BBRSBD pada Maret tahun 2017 adalah 128 penerima manfaat/siswa.Penyandang tuna daksa berjenis kelamin permpuan berjumlah 40 siswa.Penyandang tuna daksa berjenis kelamin laki-laki berjumlah 88 siswa.Penjabaran menurut latar belakang penyebab kecacatannya, penyandang tuna daksa bawaan lahir berjumlah 60 siswa dan penyandang tuna daksa akibat kecelakaan berjumlah 68 siswa.

Kehidupan di Balai ini dihuni oleh 128 orang penerima manfaat, dari berbagai macam daerah di Indonesia dengan berbagai latar belakang budaya, ras, suku, agama dan latar belakang penyebab kecacatan. Tuna daksa adalah kerusakan, kecacatan, ketidaknormalan pada bentuk tubuhnya, sebagaimana kelainan fisik pada tulang atau gangguan pada sendi atau otot yang mengakibatkan kekurangan kapasitas normal individu untuk bergerak dalam melakukan aktivitas sehari-hari (Machdan \& Hartini, 2012).

Dampak psikologis yang mengikuti penyandang cacat fisik tersebut, menurut Senra (dalam Puspasari \& Alfian 2012), antara lain: (1) Depresi yaitu dirasakannya berbagai kesulitan menggunakan kemampuan dasar pada kehidupan sehari-hari dan hilangnya kepercayaan diri yang menyebabkan perasaan rendah diri pada individu tersebut hingga menimbulkan depresi. (2) Trauma yaitu mengalami periode kesedihan dan frustasi terutama dalam proses mencapai well-being terutama ketika merasakan identitasnya berubah menjadi penyandang cacat dan merasa memiliki ketergantungan kepada orang lain. (3) Marah yaitu perasaan menyesal melakukan kegiatan tersebut, maupun tidak menyakini garis kehidupan yang sudah diberikan kehidupan yang sudah diberikan. Namun, perasaan marah dapat hilang ketika penyandang cacat fisik telah dapat berpikir secara rasional akan keadaan yang dialami. (4) Shock yaitu perasaan yang sangat sedih dan tidak menyangka keadaaannya telah berubah hingga memerlukan sangat banyak bantuan dari pihak lain. (5) Tidak dapat menerima keadaan/stress adalah subjek belum bisa mengintegrasikan atau membiasakan diri dengan tubuh barunya.Proses adaptasi dan penerimaan diri yang positif membutuhkan waktu yang lama terutama ketika kejadian tersebut terjadi dalam kehidupan normal tanpa kecacatan akan berlangsung cukup lama. (6) Berpikir untuk bunuh diri merupakan dampak ekstrem dari dampak psikologis yang mengikuti pasca kecelakaan. Sehingga dapat disimpulkan bahwa tuna daksa akibat kecelakaan memiliki andil yang besar bagi seseorang mengalami depresi. 
Menurut hasil penelitian yang pernah dilakukan oleh IIman. dan Susanti ( dalam Setyowati, Anganthi \& Asyanti, 2015). kepada 25 siswa yang mengalami difabel akibat kecelakan memperoleh hasil sebanyak 56\% siswa mengalami depresi tinggi dan sedang, sisanya sebanyak $44 \%$ mengalami depresi ringan hingga normal.

Dampak kecacatan fisik pada kecemasan dan depresi dapat mempengaruhi siapa saja, dapat dari tingkat jenis kelamin, usia, penyakit yang diderita dan durasi penyakit. Hal ini menunjukkan bahwa ada hubungan positif antara kecacatan fisik pada kecemasan dan depresi (Jones dkk, 2014). Depresi dapat terjadi pada siapa saja, pada penelitian yang telah dilakukan Maulida (2012) depresi dapat terjadi pada mahasiswa yang tidak dapat mengembangkan gaya personal, gagal membina hubungan dengan orang lain, akan memicu mahasiswa merasakan masalah yang membuat stress. Stress yang tidak tertangani akan membuat depresi.

Hasil penelitian Sulaeman (dalam Tentama, 2014) akibat dari keadaan tubuh dirinya yang tidak sempurna akibat kecelakan maupun bawaan lahir, penderita difabel yang kurang atau tidak mampu menerima dirinya akan mempunyai sikap dan perilaku mengkritik atau mencerca diri sendiri, individu memandang orang lain secara tidak adil, individu menolak dirinya, individu suka merusak dirinya sendiri dan individu sering berbuat sesuatu yang menyebabkan orang lain memandang rendah kepadanya.

Hasil penelitian yang telah dilakukan Tentama (2014) kepada 40 difabel di SLB Negeri 3 Yogyakarta bahwa ada hubungan positif yang sangat signifikan antara berpikir positif dengan penerimaan diri. Semakin tinggi kemampuan berpikir positif, maka akan semakin tinggi penerimaan diri difabel bawaan lahir. Semakin rendah kemampuan berpikir positif, maka akan semakin rendah penerimaan diri difabel bawaan lahir.

Hasil penelitian Appel \& Gerlach (2015) menunjukkan bahwa depresi berhubungan dengan tingkat kecemburuan, terutama bila standar perbandingan sosial yang tinggi.selain itu perbandingan sosial memiliki peran penting dalam permasalah ini, bahwa tidak hanya dari kelompok tertekan yang memiliki perasaan rendah diri dalam perbandingan sosial namun secara inferior juga diprediksi iri secara subtansial. Sehingga iri hati juga dapat berkorelasi dengan gejala depresi, berpikiran negatif dan harga diri.

Hasil penelitian Piran \& Ka'arayeno (2017) kepada 34 responden remaja penyandang tuna daksa di Panti Asuhan Bhakti Luhur Kecamatan Sukun Malang, menunjukkan bahwa penyandang tuna daksa bawaan atau sejak lahir sebanyak 27 orang $(79,41 \%)$, sedangkan penyandang tuna daksa kecacatan sesudah lahir sebanyak 7 orang (20,59\%). Ini menunjukkan bahwa individu yang mengalami kecacatan sejak lahir sudah mampu menyesuaikan diri dengan lingkungannya dan sudah memahami keadaan dirinya sehingga bisa menerima segala kekurangannya tersebut karena cacat fisik yang dialaminya sudah sejak lama.

Menurut hasil penelitian dari Pratiwi \& Hartosujono (2014) bahwa sebagai penyandang tuna daksa yang mampu mengatasi dan tidak pernah menjadikan permasalahan sebagai beban dan kesulitan sehingga penyanang tuna daksa masih memiliki rasa tidak direndahkan oleh masyarakat di lingkungannya, dengan pemikiran tersebut penyandang tuna daksa mempu menjalin hubungan baik dengan teman, keluarga, 
masyarakat. Adanya dukungan dari teman-teman, keluarga dan masyarakat penyandang tuna daksa dapat menghadapi masalahnya sehingga subjek tidak merasa frustasi dengan keadaannya sebagai tuna daksa.

Asadi (2016) bahwa kehidupan dan kualitas penyandang disabilitas berpengaruh terhadap berbagai faktor seperti faktor sosial, fisik, keluarga, dan banyak lagi.Faktor keluarga memiliki pengaruh besar dalam perkembangan kehidupan dan kualitas penyandang disabilitas terutama pengaruhnya terhadap faktor psikologis.

Disisi lain penyandang tuna daksa bawaan lahir yang sulit sekali menerima dirinya sendiri, bahkan mereka merasa kurang percaya diri untuk bergaul dengan teman seusia mereka dan ada yang sampai tidak menginginkan dirinya menampakkan wajah di lingkungan luar dikarenakan malu memiliki tubuh yang cacat menurut penelitian dari (Widhiasty dalam Piran, 2017).

Jadi berdasarkan uraian di atas permasalahan psikologis yang dihadapi oleh penyandang cacat di BBRSBD salah satunya adalah depresi. Cam mendefinisikan depresi sebagai sindrom yang meliputi gejala seperti berpikir dan berbicara dalam suasana hati yang menyedihkan, memiliki penurunan gerakan dan lamban, merasa tak ternilai, pesimis dan merasa kecil dan beraktivitas yang lebih lambat (Unver dkk, 2015).

Depresi merupakan penurunan energi dan perasaan senang, sehingga seseorang mengalami kesedihan, perasaan murung hingga pada keadaan tak berdaya (Hadi, 2004). Depresi terdiri dari beberapa aspek (Nevid dkk, 2009) yaitu: (1) Perubahan pada kondisi emosional, terdiri dari perubahan pada mood (periode terus-menerus dari perasaan terpuruk, depresi, sedih, atau muram). Penuh airmata atau menangis. $\begin{array}{llr}\text { Meningkatnya } & \text { iritabilitas } & \text { (mudah } \\ \text { tersinggung), } & \text { kegelisahan, } & \text { atau }\end{array}$ kehilangan kesabaran. (2) Perubahan fungsi kognitif, terdiri dari kesulitan berkonsentrasi atau berpikir jernih. Berfikir negatif mengenai diri sendiri dan masa depan. Perasaan bersalah atau menyesal mengenai kesalahan di masa lalu. Kurangnya self-esteem atau merasa tidak adekuat. Berfikir akan kematian atau bunuh diri. (3) Perubahan motivasional, terdiri dari perasaan tidak termotivasi, atau memiliki kesulitan untuk memulai (kegiatan) di pagi hari atau bahkan sulit bangun dari tempat tidur, menurunnya tingkat partisipasi sosial atau minat pada aktivitas sosial, kehilangan kenikmatan atau minat dalam aktivitas menyenangkan, menurunnya minat pada seks, gagal untuk berespon pada pujian atau reward. (4) Perubahan fungsi fisik, terdiri dari bergerak atau berbicara dengan lebih perlahan dari biasanya. Perubahan dalam kebiasaan tidur (tidur terlalu banyak atau terlalu sedikit, bangun lebih awal dari biasanya dan merasa kesulitan untuk kembali tidur di pagi buta disebut mudah terbangun di pagi buta). Perubahan dalam selera makan (makan terlalu banyak atau terlalu sedikit). Perubahan dalam berat badan (bertambah atau kehilangan berat badan). Berfungsi secara kurang efektif daripada biasanya di tempat kerja atau di sekolah.

Tuna daksa adalah individu yang memiliki gangguan gerak yang disebabkan oleh kelainan neuromuscular dan struktur tulang yang bersifat bawaan, sakit atau akibat kecelakaan, termasuk cerebral palsy, amputasi, polio, dan lumpuh (Desiningrum, 2016).

Hipotesis penelitian ini adalah ada perbedaan tingkat depresi antara penyandang tuna daksa akibat kecelakaan lebih tinggi dibanding penyandang tuna daksa bawaan lahir. 
Permasalahan ini muncul penyesuaian terhadap bentuk fisik yang tidak normal, bentuk fisik yang berbeda dengan lingkungan sekitar dan orangorang terdekat. Penyandang tuna daksa yang tidak dapat menerima keadaan dirinya sangat mudah terserang pikiran dan emosi-emosi negatif berupa cemas, malu, sedih, kurang percaya diri, perasaan tidak berguna, penyesalan, mudah marah, mengurung diri, menarik diri dari lingkungan jika berkepanjangan dapat mengalami depresi.

Oleh karena itu peneliti tertarik dengan permasalahan depresi pada tuna daksa berdasarkan latar belakang penyebab ketunadaksaan sehingga memunculkan pertanyaan peneliti "Apakah ada perbedaan tingkat depresi ditinjau dari latar belakang penyebab kecacatan pada penyandang tuna daksa ?"

\section{METODE PENELITIAN}

Metode penelitian yang digunakan dalam penelitian ini adalah metode penelitian kuantitatif.Terdapat dua variabel pada penelitian ini, yaitu: variabel bebas (x): latar belakang penyebab tuna daksa dan variabel tergantung $(\mathrm{y})$ : depresi.

Populasi penelitian ini adalah penerima manfaat BBRSBD Surakarta. Penerima manfaat di BBRSBD berjumlah 128 siswa. Teknik pengambilan sampel dalam penelitian ini adalah purposive sampling. Kriteria subjek penelitian yang dikehendaki adalah sebagai berikut: tidak buta huruf, penyandang tuna daksa akibat kecelakaan atau penyandang tuna daksa bawaan lahir, penyandang tuna daksa berada di rehabilitasi $\leq 6$ bulan, penyandang tuna daksa akibat kecelakaan dialami $\leq 20$ tahun, penyandang tuna daksa berusia 18-34 tahun. Maka didapatkan subjek penelitian berjumlah 80 siswa. Penyandang tuna daksa bawaan lahir berjumlah 40 siswa dan penyandang tuna daksa akibat kecelakaan berjumlah 40 siswa.

Metode pengumpulan data yang digunakan dalam penelitin ini adalah skala Beck Depression Inventory II (BDI-II) yang berisi pernyataan-pernyataan yang berkaitan dengan tingkat depresi. Uji reliabilitas skala depresi menggunakan alpha cronbach diperoleh nilai koefisien reliabilitas alpha $(\alpha)=0,802$. Teknik analisis data dalam penelitian ini menggunakan Independent Sampel T-test

\section{HASIL DAN PEMBAHASAN}

Berdasarkan hasil penelitian menggunakan analisis Independent Sample t-Test diperoleh hasil. sig. (2tailed) $0,029(\rho<0,05)$. dengan $t=-2,227$ Hasil ini menunjukan hipotesis diterima artinya terdapat perbedaan tingkat depresi antara penyandang tuna daksa bawaan lahir dengan penyandang tuna daksa akibat kecelakaan.

Berdasarkan dari analisis data, tingkat depresi 40 subjek penyandang tuna daksa bawaan lahir 7,38 tergolong pada kategori tidak ada gejala dan 40 subjek penyandang tuna daksa akibat kecelakaan 11,10 tergolong pada kategori rendah.

Berdasarkan hasil analisis skala depresi 80 penyandang tuna daksa di BBRSBD diketahui rerata empirik (RE) sebesar 9,24 dan rerata hipotetik $(\mathrm{RH})$ sebesar 31.5 yang berarti tingkat depresi pada subjek tergolong rendah. Hasil ini menunjukkan bahwa tingkat depresi penyandang tuna daksa di BBRSBD tergolong pada kategori rendah.

Pada data awal penelitian ini menunjukkan asumsi bahwa depresi pada kategori sedang/tinggi namun setelah penelitian menunjukkan tingkat depresi tergolong pada kategori rendah hal ini dapat disebabkan masa tinggal 
penyandang tuna daksa berada direhabilitasi berbeda dengan masa tinggal penyandang tuna daksa pada pengumpulan data awal.Masa tinggal penyandang tuna daksa ketika pengumpulan data awal selama 1 minggu. Masa tinggal penyandang tuna daksa ketika pengumpulan data penelitian selama 6 bulan.

Hal ini sesuai hasil penelitian Bujawati dkk (2015) bahwa sebelum menjalani proses rehabilitasi responden mengakui bahwa mereka pernah merasa tidak adil atas kedisabilitasannya, dan merasa malu terhadap orang lain, sehingga sulit bagi responden untuk bersosialisasi dengan nyaman. Selain itu mereka pernah merasa tidak berarti atas kedisabilitasannya sehingga sering merasa gusar dan terkadang marah, sehingga mereka selalu bergantung terhadap orang disekitarnya untuk menyelesaikan kegiatan mereka. Tetapi setelah mereka mengikuti proses rehabilitasi, banyak perubahan dalam diri mereka. Mereka merasa lebih berharga setelah dibekali ilmu dan keterampilan yang didapatkan dari kegiatan rehabilitasi, mereka mampu menyesuaikan diri dengan orang-orang di lingkungan tempat rehabilitasi dan mereka mengatur dan menyelesaikan sendiri rutinitas mereka tanpa melibatkan banyak bantuan dari orang lain.

Hal ini sesuai hasil penelitian Jones dkk (2014) hal ini menunjukkan bahwa dampak kecacatan fisik pada kecemasan dan depresi dapat mempengaruhi siapa saja, dapat dari tingkat jenis kelamin, usia, penyakit yang diderita dan durasi penyakit. Ini menunjukkan bahwa ada hubungan positifantara kecacatan fisik pada kecemasan dan depresi.

Pratiwi \& Hartosujono (2014) bagi keempat subjek menjadi penyandang tuna daksa bukan menjadi suatu masalah lagi, melainkan sebagai suatu ujian dan bukan merupakan kesulitan untuk melakukan suatu kegiatan.Memiliki tubuh yang tidak normal, tidak membuat subjek putus asa dan seiring berjalannya waktu subjek dapat menerima keadaan dirinya.

Hasil penelitian kepada 80 penyandang tuna daksa.Penyandang tuna daksa berjenis kelamin perempuan berjumlah 17 siswa dan penyandang tuna daksa berjenis kelamin laki-laki berjumlah 63. Penyandang tuna daksa berjenis kelamin perempuan mengalami depresi pada kategori sedang-tinggi berjumlah 4 siswa $(23,5 \%)$. Penyandang tuna daksa berjenis kelamin laki-laki mengalami depresi pada kategori sedang-tinggi berjumlah 13 siswa (20,6\%). Supriyadi (2008) hasil penelitian mengatakan bahwa adanya perbedaan tigkat depresi antara pria dan wanita disebabkan karena adanya perbedaan dalam menyikapi situasi yang menimbulkan depresi seperti adaptasi terhadap kondisi dan lingkungan, daya juang, optimisme.

Perubahan pada kondisi fisik yang terjadi pada tuna daksa akibat kecelakaan dapat mempengaruhi perubahanperubahan lain yang terjadi pada diri, terdapat 4 perubahan yang terjadi meliputi perubahan emosi, perubahan motivasi, perubahan fungsi motorik, perubahan kognitif. Tuna daksa akibat kecelakaan mengalami perubahan kondisi fisik yang terjadi dari kondisi fisik sebelumnya sehingga tuna daksa akibat kecelakaan memungkinkan terjadinya perubahan emosi, kognitif, motorik, motivasi yang terjadi pada perilaku terhadap diri sendiri, lingkungan dan kekhawatiran masa depannya (Nevid dkk, 2009).

Hal tersebut sesuai dengan gagasan Keliat \& Susanti (2011) mengemukakan beberapa faktor penyebab seseorang mengalami depresi meliputi faktor biologis dan faktor lingkungan.Faktor biologis berupa faktor genetik.Faktor lingkungan 
meliputi kehilangan orang yang dicintai, kemarahan, kekecewaan yang ditunjukan pada suatu objek atau pada diri sendiri, mengalami kesulitan hidup, hingga pengalaman berperilaku dan pengalaman masa lalu yang bergantung dengan lingkungan.

Berdasarkan dari analisis data, tingkat depresi 40 subjek penyandang tuna daksa bawaan lahir 7,38 tergolong pada kategori tidak ada gejala dan 40 subjek penyandang tuna daksa akibat kecelakaan 11,10 tergolong pada kategori rendah.

Hal ini sesuai hasil penelitian Piran \& Ka'arayeno (2017) bahwa individu yang mengalami kecacatan sejak lahir sudah mampu menyesuaikan diri dengan lingkungannya dan sudah memahami keadaan dirinya sehingga bisa menerima segala kekurangannya tersebut karena kecacatan fisik yang dialaminya sudah sejak lama.

Menurut hasil penelitian dari Pratiwi \& Hartosujono (2014) bahwa sebagai penyandang tuna daksa yang mampu mengatasi dan tidak pernah menjadikan permasalahan sebagai beban dan kesulitan sehingga penyanang tuna daksa masih memiliki rasa tidak direndahkan oleh masyarakat di lingkungannya, dengan pemikiran tersebut penyandang tuna daksa mempu menjalin hubungan baik dengan teman, keluarga, masyarakat. Adanya dukungan dari teman-teman, keluarga dan masyarakat penyandang tuna daksa dapat menghadapi masalahnya sehingga subjek tidak merasa frustasi dengan keadaannya sebagai tuna daksa.

Adanya perbedaan tingkat depresi dan disabilitas menurut Riskesdas tahun 2007 dan tahun 2013 menunjukkan bahwa responden yang memiliki gangguan emosional berat diketahui memiliki kondisi disabilitas yang juga berat, sangat berat, baik pada hasil riskesdas tahun 2007 (4,1\%) maupun 2013 (3,3\%). Responden yang tidak menderita disabilitas tetap mempunyai kecenderungan mengalami gangguan mental emosional menurut hasil Riskesdas 2007 dan 2013, walaupun angkanya kecil pada gangguan mental emosional ringan $(3,5 \%$ dan $1,9 \%)$, sedang $(0,5 \%$ dan 0,3$)$ dan berat $(1,2 \%$ dan $0,2 \%$ ). (Wardhani, Yurika \& Paramita, 2016).

Table 1.

Independent Sample t-Test

\begin{tabular}{llccc}
\hline & & \multicolumn{3}{c}{ t-test for Equality of Means } \\
& & $\mathrm{t}$ & $\mathrm{df}$ & Sig. (2-tailed) \\
\hline Tingkat & Equal variances assumed & $-2,227$ & 78 & .029 \\
depresi & Equal variances not assumed & $-2,227$ & 71,589 & .029 \\
\hline
\end{tabular}

\section{SIMPULAN}

Berdasarkan hasil penelitian menggunakan analisis uji hipotesis diperoleh hasil Asymp.sig. (2-tailed) 0,029 dengan $t=-2,227(\rho<0,05)$. Hasil ini menunjukan terdapat perbedaan tingkat depresi antara penyandang tuna daksa bawaan lahir lebih rendah dibanding penyandang tuna daksa akibat kecelakaan.

Saran bagi tuna daksa dengan membiasakan diri untuk selalu berpikiran positif serta membuang pemikiranpemikiran yang negatif tentang dirinya 
terhadap lingkungan dan orang lain. Menambah ketrampilan dengan program tambahan yang telah disediakan di Balai Pelatihan agar memambah ketrampilan yang dimiliki untuk mengurangi perasaan - perasaan negatif.
Saran bagi bagi peneliti selanjutnya bagi peneliti selanjutnya diharapkan mampu memperbaiki kualitas dalam penelitian yang telah dilakukan guna mendapatkan hasil yang maksimal baik dalam tata tulis, konten dan subjek dalam penelitian.

\section{DAFTAR PUSTAKA}

Appel, H., Crusius.J., \& Gerlach, A. I. (2015). Social comparison, envy, and depression on facebook: A study looking at the effects of high comparison standards on depressed individuals. Journal of Social and Clinical Psychology, 34(4), 277-289.

Asadi, R. (2016). Studying the influence of family members' depression on the life quality of the disabled with an emphasis on their spiritual and mental health.Journal of Studies in Social Sciences and Humanities, 2(4), 138-142.

Bujawati, E., Sukfitrianti., Sari, A. P. (2015). Hubungan proses rehabilitasi terhadap perkembangan psikososial penyandang tuna daksa di Panti Sosial Bina Daksa Wirajaya Makassar tahun 2015. Al-Sihah : Public Health Science Journal, 7(2), 140152.

Cicilia, S. (2016, Januari 10).Jumlah kecelakaan kerja di Indonesia masih tinggi.Kontan.co.id. diunduh dari https://kontan.co.id.

Desiningrum, D. R. (2016). Psikologi anak berkebutuhan khusus. Yogyakarta: Psikosain.

Diono, A., Mujaddid., Prasetya, F., Budijanto, D. (2014, Desember). Situasi penyandang disabilitas.Buletin Jendela Data \& Informasi Kesehatan (2), 1-56.

Fachrudin, F. (2015, Desember 3).Penyandang disabilitas di indonesia mencapai 9 juta jiwa. Okezone.com. diunduh dari http://news.okezone.com.

Hadi, P. (2004). Depresi dan solusinya. Yogyakarta: Tugu Publisher.

Jones, K., Jones, P., Middleton, R., Ford, D., Dalton, K, et al. 2014. Physical disability, anxiety and depression in people with ms: an internet-based survey via the UK MS Register. Journal One 9(8), 1-9.

Keliat, B., Wiyono, A., \& Susanti, H. (2011). Managemen kasus gangguan jiwa. Jakarta: Buku Kedokteran EGC.

Machdan, D., \& Hartini, N (2012).Hubungan antara penerimaan diri dengan kecemasan menghadapi dunia kerja pada tunadaksa di PT UPT Rehabilitasi Sosial Cacat Tubuh Pasuruan.Jurnal Psikologi Klinis dan Kesehatan Mental, 1(02), 79-85. 
Mardianto, B. (2016, April 22). Ini 5 negara tingkat kecelakaan lalu lintas tertinggi di Dunia. iyaa.com. diunduh http://iyaa.com

Maulida, A. (2012). Gambaran tingkat depresi pada mahasiswa program sarjana yang melakukan konseling di Badan Konseling Indonesia di Universitas Indonesia. Skripsi. Fakultas IImu Keperawatan Universitas Indonesia, Jakarta.

Nevid, J., Rathus, S., \& Greene, B. (2009). Psikologi abnormal jilid 1 (ed.5). Jakarta: Erlangga.

Piran, A., Yuliwar. R., \& Ka'arayeno, A. (2017).Hubungan antara penerimaan diri dengan kepercayaan diri dalam interaksi sosial pada remaja penyandang cacat fisik di Panti Asuhan Bhakti Luhur Kecamatan Sukun Malang.Nursing News, 2(1), 578-597.

Pratiwi, I., \& Hartosujono (2014). Resiliensi pada penyandang tuna daksa non bawaan.Jurnal SPIRITS, 5(1), 48-54.

Puspasari, D., \& Alfian, I. N. (2012).Makna hidup penyandang cacat fisik postnatal karena kecelakaan.Jurnal Pskologi Klinis dan Kesehatan Mental 1(2), 151-157.

Setyowati, R., Anganthi, N., \& Asyanti, S. (2015). Depresi pada difabel akibat kecelakaan. Indigenous: Jurnal IImiah Psikologi, 13(2), 87-93.

Supriadi, Y. (2008). Perbedaan tingkat depresi antara pria dan wanita pasca stroke.Skripsi. Fakultas Psikologi Universitas Sanata Dharma, Yogyakarta.

Susilawati, D., \& Aminah, A. (2016, Desember 16).Indonesia miliki 12 persen penyandang disabilitas. Republika.co.id. http://news.okezone.com

Susilowati, T., \& Hasanat, N. (2011). Pengaruh terapi menulis pengalaman emosional terhadap penurunan depresi pada mahasiswa tahun pertama.Jurnal psikologi, 38(1), $92-107$.

Tentama, F. (2014). Hubungan positive thingking dengan self-acceptance pada difabel (bawaan lahir) di SLB Negeri 3 Yogyakarta.Jurnal Psikologi Integratif, 2(2), 1-7.

Unver, S., Atan, C., Cavasoglu, G., \& Erim, V. (2015).A comparison of levels of quality of life, depression and loneliness among athletes with difference training. Academic Journals , 10(2), 130-134. 